\title{
Communication Pattern of Wilayatul Hisbah, Lhokseumawe City in Implementing Amar Makruf Nahi Mungkar
}

\author{
Hasbullah ${ }^{1,3}$, Mohd. Hatta ${ }^{2}$, Zainal Arifin ${ }^{2}$ \\ ${ }^{1}$ Postgraduate Student at State Islamic University of North Sumatera (UINSU), Medan, Indonesia \\ ${ }^{2}$ State Islamic University of North Sumatera (UINSU), Medan, Indonesia \\ ${ }^{3}$ Islamic Religion Institute (IAI) of Al-Aziziyah Samalanga, Bireuen, Indonesia \\ tgkdrsaiful@gmail.com
}

\begin{abstract}
Communication is the process of delivering messages by someone to other people to tell, change attitudes, opinions or behavior either directly orally or indirectly through the media. In this communication requires a reciprocal relationship between the delivery of messages and recipients namely communicators and communicants. The purpose of Islamic communication is to give good news with the shadow of the multiplication of fahala and the recompense of heaven, giving news of fear of the threat of doom, and the reward of hell. And invite the people to understand and forbid from evil deeds, and remind those who are negligent, and teach and guide those who are ignorant. The type of research contained in this dissertation is qualitative. Qualitative research is a study that aims to understand the phenomena or social realities that arise in society which are subject to holistic research, and by describing in the form of words and languages in a special context that is natural by utilizing various natural methods. The approach that the researchers used in this study was case studies. In this study, researchers explored the patterns of communication carried out by members and institutions of the Wilayatul Hisbah in implementing amar ma'ruf nahi munkar in Lhokseumawe City.
\end{abstract}

Keywords: Islamic communication; Wilayatul Hisbah; Lhokseumawe city; social realities; communication pattern

\section{Introduction}

The purpose of Islamic communication is to give good news with the shadow of the multiplication of fahala and the recompense of heaven, giving news of fear of the threat of doom, and the reward of hell. And invite the people to understand and forbid from evil deeds, and remind those who are negligent, and teach and guide those who are ignorant.

According to the Social Sciences view the term Change and development that develops in the West is very closely related to Amar Ma'ruf nahi Munkar in the concept of Islam. ${ }^{1}$ In this concept the Islamic community has a moral responsibility towards other Muslims to make improvements, change (change) the pattern of one's life in a better direction and prevent acts that deviate from Islamic values, and call for faith in Allah. Islam also emphasizes on Muslims and Muslim women to create healthy communities that are free from corruption and despicable acts and to always behave well and avoid tyranny. This mandate is the principles of amar ma'ruf nahi munkar.

This is the basis for the purpose of Islamic communication to give good news with the shadow of multiple rewards and recompense of heaven, giving news of fear of the threat of punishment, and reprisal of hell. Also invites the people to the formal juridical and prohibits

\footnotetext{
${ }^{1}$ M. Tata Taufiq, Etika Komunikasi Islam: Komparasi Komunikasi Islam dan Barat, (Bandung: Pustaka Setia, 2012). p. 232.
} 
the evil deeds, and reminds those who are negligent, and teaches and guides those who are ignorant.

\section{Review of Literature}

\subsection{Definition of Communication Patterns}

Before researchers discuss further about communication patterns, then first need to know about what communication is. The term communication in English is communication, derived from the Latin word communicatio, and comes from the word communis which means the same,the same here means the same meaning. Communication is the main means that is often used both verbally and non-verbally, communication is used both in personal interests and in common interests, and in an organization communication is also always used to achieve satisfaction and achieve common goals. Communication can be interpreted as verbal and non verbal conversations or between one more person and another. ${ }^{2}$ According to Hovland, communication is a systematic effort to formulate rigorously the principles of delivering information and the formation of opinions and attitudes. ${ }^{3}$

In another sense communication is the process of sending messages from one party to another through certain contexts such as intrapersonal communication, interpersonal or interpersonal communication, group communication or organizational communication and mass communication. When communication takes place in the context of group communication or organizational communication, it will have its own communication network or pattern.

Whereas Communication in the view of Ruben and Stewart as quoted by Alo Liliweri is something that is needed for every individual, relationship, group, organization, and society. Communication is a channel connecting humans to the natural surroundings. In the sense of how the human is interpreting and giving an impression of nature around it. Communication is also one of the instruments for humans to show their true identity, and influence others. Therefore, if humans are not good at communicating, then humans are considered to fail in interacting with the natural environment, both with individuals, groups, and society. That person is also considered unable to build and maintain relations between each other.

\subsection{Islamic Communication Pattern}

Religious communication (religious communication) does indeed include Islamic communication but is not the same as Islamic communication because religious communication encompasses all religions. Even though Islam is different from other religions especially regarding its teachings. It is necessary to distinguish between Islamic communication and Islamic communication. Islamic Communication is a communication system for Muslims. This means that, Islamic communication is more focused on the system with a philosophical background (theory) that is different from the non-Islamic communication perspective. In other words the Islamic communication system is based on the Qur'an and Hadith.

From the explanation above, convergence (meeting) finally occurred between the notion of Islamic communication and Islamic communication. It could be said, Islamic

\footnotetext{
${ }^{2}$ Onong Uchjana Effendy, Ilmu Komunikasi. Teori dan Praktek, (Bandung: Rosdakarya, 2008), p.10

${ }^{3}$ Ibid.
} 
communication is the implementation (how to implement) Islamic communication. Husaini gave the definition of Islamic communication as a process of conveying messages or information from communicators to communicants using the principles and communication methods contained in the Qur'an and Hadith.

As for Syukur Kholil, Islamic communication is the process of delivering or passing the nature of the truth of Islam to the public which is carried out continuously by referring to the Qur'an and al-Sunnah either directly or indirectly, through the mediation of general or specialmedia, which aims to form a general view based on the nature of religious truth and give an impression to one's life in the aspects of aqeedah, worship and muamalah.

From the explanation above, it can be understood that Islamic communication is the process of delivering divine and nabawiyah messages, meaning the process of delivering messages based on divine revelations and messages originating from the Messenger of Allah to the public to foster an understanding of religion for them.

\subsection{Organizational Communication Pattern}

The term organization comes from Latin organizare which literally means a mixture of parts of one another that are interdependent. Among the experts there are those who call this alloy a system and some call it a facility. ${ }^{4}$ The correlation between the science of communication with the organization lies in its review which focuses on the people involved in achieving the goals of the organization.

The organization itself consists of a number of people who are interdependent. Dependence requires coordination, and coordination requires communication. Such is the relationship between communication and organization stated by William V. Hanney. ${ }^{5}$

Then it can be said that when talking about organizations it will not be separated from communication because communication is a sine qua non for the organization. Communication is very important in building relationships between people involved in an organization. Each member of the organization that has a personal interest unites to form a common interest.

When humans communicate within an organization, they need a system to regulate the flow of information. Not only large-scale organizations that have such a high level of complexity but also small-scale organizations. ${ }^{6}$

With the existence of an information flow control system, each member of the organization can find out "who is talking to whom". This system by Ronald Adler et al. Is called communication networks, namely a pattern of regular relations between individuals and other individuals where the flow of information runs within an organization.

\subsection{Interpersonal Communication}

Communication is the process of delivering messages by someone to other people to tell, change attitudes, opinions or behavior either directly orally or indirectly through the media. In this communication requires a reciprocal relationship between the delivery of messages and recipients namely communicators and communicants.

According to Carl I. Hovland, the science of communication is a systematic effort to formulate explicitly the principles of information delivery and the formation of opinions and

\footnotetext{
${ }^{4}$ Khomsahrial Romli,Komunikasi Organisasi Lengkap,( Jakarata:Grasindo,214), p,1

${ }^{5}$ Onong Uchjana Effendy, Ilmu Komunikasi..., p.146

${ }^{6}$ Ibid.
} 
attitudes. Broadly speaking, it can be concluded that communication is the delivery of information and a person's understanding of others.

Wayne Pace (1979) argues that interpersonal communication or interpersonal communication is a communication process that takes place between two or more people face to face where the sender can deliver the message directly and the recipient of the message can receive and respond directly.

Interpersonal communication is communication whose message is packaged in the form of verbal or nonverbal, such as communication in general interpersonal communication always includes two main elements, namely the content of the message and how the content of the message is said or done verbally or nonverbally. These two elements should be considered and carried out based on consideration of the situation, condition, and condition of the recipient of the message.

Interpersonal communication is an active activity not passive. Interpersonal communication is not only communication from the sender to the recipient of the message, and vice versa, but reciprocal communication between the sender and the recipient of the message. Interpersonal communication is not just a series of stimuli-responses, stimulusresponses, but a series of processes of mutual acceptance, seizure and delivery of responses that have been processed by each party.

Interpersonal communication also has a role to change and develop each other. And these changes through interaction in communication, the parties involved to inspire, enthusiasm, and encouragement in order to be able to change thoughts, feelings, and attitudes according to the topics studied together. Interpersonal communication or interpersonal communication is the process of exchanging information and transfer of understanding between two or more people from a small group of people with various effects and feedback (feedback).

In order for interpersonal communication to be carried out to produce effective interpersonal relationships and cooperation can be improved, we need to be open, trusting, supportive, and open, which encourages attitudes that best understand, respect and develop mutual qualities.

\section{Research Methodology}

To obtain answers to the questions raised in the formulation of the problem, an appropriate research methodology is needed, so that the research data needed can be obtained and the accuracy can be accounted for. For this reason, the type of research contained in this dissertation is qualitative. Qualitative research is a study that aims to understand the phenomena or social realities that arise in society which are subject to holistic research, and by describing in the form of words and languages in a special context that is natural by utilizing various natural methods.

The approach that the researchers used in this study was case studies. According to John W. Creswell, case studies are investigative strategies, where the researcher explores in depth about part or all of the activity, as well as the process of the phenomenon being examined. The researcher collects information in detail using various processes for collecting data over a continuous period of time. In this study, researchers explored the patterns of communication carried out by members and institutions of the Wilayatul Hisbah in implementing amar ma'ruf nahi munkar in Lhokseumawe City. 


\section{Discussion}

Along with the development of the situation of the government system in Indonesia after the reformation in 1998, various government affairs were previously regulated by the central government, then after reform there were several functions in the regions returned by the center to be regulated by the regions.

In this case the central government provides the broadest possible authority to the government and the local / local community to be held to increase the welfare of the community. Furthermore Syaukani, HR et al. Expressing, There are quite a number of reasons why this should be chosen as one of the patterns of relations between the Central Government and the local Government. Governmental and Political circles in general have identified a number of reasons why desantralization needs to be implemented in a country, namely as follows: ${ }^{7}$

1. In order to increase the efficiency and effectiveness of governance

2. As a vehicle for community political education in the region

3. In order to maintain the integrity of the unitary State or the integration of the Center.

4. To declare democracy in the administration of Government starting from the region

5. To provide opportunities for the community to shape careers in the fields of Politics and Government,

6. As a vehicle needed to provide opportunities for the community in the process of planning and implementing Government.

7. As a means needed to accelerate development in the Region, and;

8. To create a clean and authoritative Government.

This has led to the birth of the Law on Aceh Government with the broadest principle of autonomy in the political sphere to the people of Aceh and managing regional government in accordance with the principle of good governance, namely transparent, accountable, professional, effective and intended to maximize the prosperity of the people in Aceh. in the implementation of the widest possible autonomy, the Acehnese have a role, both in formulating, stipulating, implementing and evaluating regional government policies. ${ }^{8}$

Van Der Pot in Koesoemahadmadja said that the concept of autonomy is eigen huishounding (running one's own household). Autonomy is the granting of rights to the region to regulate its own territory and the region has the freedom of initiative in the administration of governmental households in the region. ${ }^{9}$

The Central Government with the DPR has the duty to regulate the implementation of Regional Government with Legislation as a mandate from the results of Amendments to Articles 18, 18 A and 18 B of the 1945 Constitution, then Law Number 32 Year 2004 concerning Regional Government was born. considering Article 18B Paragraph (1) Stating that the State recognizes and respects Special / Special Regional Government units regulated by Law. ${ }^{10}$

\footnotetext{
${ }^{7}$ Syaukani,HR,Afan Gaffer dan Syaas,Otonomi Daerah dalam Negara Kesatuan, (Jakarta: Pustaka Pelajar, 2003), p. 17.

${ }^{8}$ Ibid, p.18.

${ }^{9}$ R.D.H. Koesoemadja, Pengantar Kearah System Pemerintahan Daerahdi Indonesia, (Badung: Bina Cipta, 1999), p. 15

${ }^{10} \mathrm{Ibid}, \mathrm{p} .19$.
} 
Law No. 11 of 2006 concerning the Government of Aceh which was born out of the Privileges of the Aceh Province and its specificity in the fields of religion, adat, education and the role of ulama. Likewise, the Papua Province recognizes the role of the Adat Assembly and Yogyakarta in terms of the appointment of governors from the descendants of the Sultanate and the specificity of the Jakarta City Ladies. ${ }^{11}$

The Era of Regional Autonomy, many of which were issued with Nuances of Islamic Sharia almost all Provinces in Indonesia applied, this is a right determined in the second amendment to Article 18 Paragraph (6) of the 1945 Constitution which states, Regional Governments have the right to stipulate Regional Regulations and other Regulations to implement Autonomy and co-administration tasks.

Acehnese are predominantly Muslim and are regions that have been given specificity and privileges for the Aceh Province, which is then uniformed from the Nanggroe Aceh Darussalam designation to Acehnese with Aceh Governor Regulation No. 46 of 2009 dated 7 April 2009. ${ }^{12}$

The Aceh Government was given the authority to implement Islamic Shari'a based on article 125 of the Aceh Government Law, which states that Islamic Sharia implemented in Aceh includes Aqeedah, Syar'iyah and Akhlak. and Islamic Shari'a as meant in Paragraph (1) includes Worship, Ahwal al-Syakhshiyah (Family Law), Muamalah (Civil Law), Jinayah (criminal law), Qadha (Judicial), Tarbiyah (Education), Da'wah, Syiar, and defense of Islam. then the Regional Government with the Acehnese people should support and carry out the implementation of Islamic Shari'a, which is rightly supposed to be cultured and Islamic in various aspects of life naturally guided by the Faith and Charity which can be accounted for before humans (human) and God. ${ }^{13}$

In its implementation, the Aceh Government has several instruments to codify the Islamic Shari'a Regulations formally. The legal instrument consists of Qanun which discusses specific issues such as Qanun concerning the issue of enforcing Islamic Sharia in the process of making Qanun, the Aceh People's Legislative Assembly (DPRA) has a large role as a Legislative Institution on a Qanun similar to a Regional Regulation. it's just that in the manufacturing process, an Institute namely the Ulama Consultative Assembly (MPU) consisting of Ulama from all Provinces acts as partners for the DPRA and weighs policy so that the formulated Qanun remains in accordance with the Islamic Sharia values prevailing in the Aceh province. ${ }^{14}$

The Qanun must be in accordance with the applicable law in Indonesia. If not, it can be tested materially in the Constitutional Court. To carry out the Qanun, the Aceh Government will establish several institutions to optimize the implementation of Islamic Law. According to the Aceh Governance Law, law enforcement against the Qanun was carried out by the Wilayatul Hisbah Police (WH). ${ }^{15}$

Wilayatul Hisbah is a new government institution that was introduced in Aceh. In the classical period of the Aceh Sultanate, a special institution was not established to implement amar ma'ruf nahi munkar. This task at that time was sufficiently carried out by ulama, imum gampong, geuchik, and respected ureung tuha, especially at that time, the Acehnese had a

\footnotetext{
${ }^{11}$ Tresna,Bertamasya Ketaman Ketatanegaraan,(Bandung : Dibya,1998). p.33.

12 Ibid, p. 19.

${ }^{13}$ Ibid, p. 20.

${ }^{14}$ Ibid, p. 21

15 Ibid, p. 22.
} 
high religious awareness, so that the existence of a government institution whose task was only to monitor the implementation of Shari'a was not felt need. Each individual with the awareness of each of them being an officer of the Wilayatul Hisbah, rebuked and reminded his brother if they did a case that was against the Shari'a and always invited his brother to do the actions of the Prophet which was recommended by Shari'a. ${ }^{16}$

Judging from its history, the Wilayatul Hisbah in Aceh stands in line with the implementation of Islamic Law which requires a supervisory institution. the existence of this institution is legally valid through Qanun Number 11 of 2002 Article 14 chapter VI and Qanun Number 12 of 2003 Article 16 to 18. Then in the next Qanun it is stated that the authority and provisions imposed on the Wilayatul Hisbah are driving the success of Islamic Sharia in Aceh.

As an integral part, the Wilayatul Hisbah has a broad role in the implementation of Islamic Shari'a, not only in the supervisory function, but also in Socialization and Coaching. Therefore, the Wilayatul Hisbah is not only tasked with overseeing and reminding the public, but they are also the perpetrators and are tasked with introducing Islamic Shari'a related to the law and moral actions to the community.

In article 144 Paragraph (2) the Law on Aceh Government states that: The Wilayatul Hisbah Police is an enforcer and supervisor of the implementation of Islamic Shari'a and an integral part of the Civil Service Police. In carrying out its duties, the Wilayatul Hisbah Police can arrest and impose sanctions when confronting Qanun violations committed by the community.

In carrying out its duties, the Wilayatul Hisbah Police is supported by a judicial institution, namely the Mahkamah Syar'iyah, the Syar'iyah Court is positioned to prosecute and settle cases in the form of the Jinayah (Criminal) case, Ahwalasy-Syakhsiyah (family law), Muamalah (Civil law), which is based on Islamic Shari'a. The Syar'iyah Court only has the right to try the Acehnese people who are Muslim, while if non-Islamic communities are involved in legal matters, they will be subject to sanctions in accordance with the Criminal Code and not follow the Qanun.

Wilayatul means Region or Area of Power, while Hisbah means calculating / assuming to be from Arabic, while Imam Al-Mawardy briefly defines that: Wewenag to run amar maufuf if people neglect, and it is impossible to see if someone does it. in general wilayatul hisbah is an institution formed by the government and paid by the government, to him given the authority to oversee the running of Islamic law and act decisively against people who do munkar and are obliged to provide assistance to those in need.

In the Aceh province known as an institution / agency better known as the Wilayatul Hisbah (WH) and this institution was actually implemented in the beginning of the Kingdom of Aceh and this system was also found in the Kitab fiqh (as-Siyasatusy Syar'iyyah, anNuzhumul Islamiyah / Al-Ahkamus Sulthaniyyah).

The establishment of the Wilayatul Hisbah institution or body in the Aceh region can accommodate phenomena that occur in the community and apply all policies or provisions in Islamic Sharia in communities domiciled in Wilayatul that have implemented Islamic Sharia.

Wilayatul Hisbah (WH) has the task of carrying out amar makruf if it seems obvious that people neglect it and do the wrongdoing if it seems real people do it. Wilayatul Hisbah

\footnotetext{
${ }^{16}$ Furqoni dalam Rena Kinnara Arlotas, Gambaran Coping Stres pada Wilayatul Hisbah yang di Tempatkan di Desa, (Medan: USU Repository, 2010). p.48.
} 
has a very large and extensive task, therefore Ibn Khaldun equalizes the functions of the Wilayatul Hisbah with the function of the Khilafah (Government).

The task of the Wilayatul Hisbah is to monitor whether or not everything that is ordered and prohibited by the Shari'a in society. its obligations are not limited in terms of orders to wear headscarves, orders to carry out people who neglect Friday prayers, prohibit various acts and mischief, but also in the economic field, such as overseeing the practice of buying and selling from usury, gharar, and cheating, overseeing the usual scales in use, ensuring that there is no hoarding of goods that is detrimental to the community, supervising Halal food, also socio-cultural aspects, such as prohibiting entertainment activities that are contrary to Islam, eradicating oxtail gambling, liquor, a-susila practice and others.

Wilayatul Hisbah enters small alleys in gampong, every day the work is Amar Makruf Nahi Mungkar, no Shari'a case escapes his attention. Wilayatul Hisbah is an institution that campaigns every day to foster Islamic Sharia awareness and oversee its implementation in the community. Therefore, the good Wilayatul Hisbah is the one who is more often in the streets, in the market, in the villages monitoring the implementation of Shari'a by the community, rather than just being in the office.

In Qanun Number 11 of 2002 in Article 14 it is stated that the task of Wilayatul Hisbah is to supervise, regulate / advise Sharia violators until the violator does not repeat his actions, if the WH's warning and advice make the individual no longer repeat his actions, then the resolution is met. advice, but if it is not heard, the supervisor submits his case to the investigator and is then handed over to the prosecutor and to be delegated to the shari'ah court.

In a decree letter from the Governor of Nanggroe Aceh Darusssalam Province No. 01 of 2004 it was stated that the task of the Wilayatul Hisbah was to supervise, guide and advocate spiritually and delegate cases to investigators. As one of the supervisory bodies acting as the Sharia Police, the Islamic Wilayatul has three task groups.

1. Main tasks are:

a. Supervise the implementation and violation of legislation in the field of Islamic Sharia

b. Conducting spiritual guidance and advocacy against anyone who is based on preliminary evidence should be suspected of having committed violations of legislation in the field of Islamic Sharia

c. When the coaching task starts from the Muhtasib (as the WH) it is necessary to inform the nearest investigator or the Keuchik / Head of the Village and the family of the perpetrator.

d. Delegate cases of violations of Laws and Regulations in the field of Islamic Law to investigators

2. Tasks related to supervision include:

a. Notify the public about the existence of legislation in the field of Islamic Sharia

b. Finding any violations of the provisions of Islamic Sharia

3. Tasks related to coaching include:

a. The Minister of Religion warned and advised someone who should be suspected of having violatedthe provisions of Islamic Sharia

b. Attempting to stop activities / actions that should be suspected of violating laws and regulations in the field of Islamic Sharia

c. Complete the violation case through the Gampong Customary Meeting 
d. Notifying the relevant party of the alleged misuse of the use of a place or facility permit.

The authority of Wilayatul Hisbah according to Abubakar states that in accordance with the Governor's decree Number 01 of 2004 concerning the Organization and work procedures of the Wilayatul Hisbah authorized in handling every violation and fostering Islamic Sharia in the Province of Nanggroe Aceh Darussalam, the authority are: ${ }^{17}$

a. Supervise the implementation of regulations and legislation in the field of Islamic Sharia

b. Reprimand, advise, prevent and prohibit any person who is reasonably suspected to have been or will violate legislation in the field of Islamic Sharia

Every Wilayatul Hisbah apparatus has the authority, namely:

a. Receive complaints reports from the public

b. Order to stop individuals suspected of being violators

c. Request information on the identity of each person who is reasonably suspected to have been and is committing a violation

d. Stop activities that are reasonably suspected of violating legislation.

The Wilayatul Hisbah also has the authority to impose penalties on people who have been proven to violate Islamic Sharia. of course the sentence is in the form of ta'zir, which is a sentence that is decided based on the wisdom of the judge outside the form of punishment determined by syara '. Sentences imposed by the judiciary. Wilayatul Hisbah may burn Porno VCDs, confiscate items piled up by traders so that they organize the community and then distribute the shares to the poor, threaten defamation, to parade the offenders around the city and hang up the writing "I have violated Islamic Sharia and will not repeat it"18

When sentencing, the Wilayatul Hisbah must already have enough evidence and indeed it is evident (evident) that individuals truly violate the Shari'a, or it seems clear that individuals leave the Shari'a case. Because the WH cannot be arbitrary, especially if it is only based on prejudices which is not necessarily true.

This is important because the community is certainly very sensitive to all forms of punishment, especially if it turns out that they do not violate the Shari'a or are only based on the prejudice of the Wilayatul Hisbah. Mistakes to punish will make the community apathetic towards the Shari'a and consider the Shari'a disturbing their freedom of privacy. ${ }^{19}$

The pattern of communication is essentially, the process of conveying thoughts or feelings of a communicator to the communicant. Thoughts in the form of ideas, ideas, information, problems, which arise in the mind.Feelings in the form of beliefs, worries, sadness, joy that arise and deep down. In the communication pattern, what is in the mind of the communicator is translated (encoding) in the form of a message / message with a language which according to its perception can be understood by the communicant then the communicant interprets (decoding) the message in accordance with his own understanding.

The communicant pattern responds to the message that is conveyed so it provides feedback (feedback through the encoding / decoding process as above. In communication patterns there may be obstacles due to noise (noise) so that the message delivered does not reach the target as expected.

\footnotetext{
${ }^{17} \mathrm{Al}$ Yasa Abubakar, Wilayatul Hisbah: Polisi Pamong Praja dengan Kewenangan Khusus di Aceh, (Banda Aceh: Dians Syariat Islam Provinsi Aceh, 2009), p. 20.

${ }^{18} \mathrm{Ibid}$.

${ }^{19} \mathrm{Ibid}, \mathrm{p} .77$.
} 
In this study the researcher used the theory of interpersonal communication and interpersonal communication as well as the policy implementation model of George Edward III. Interpersonal communication is communication between someone and other people face to face, which allows each participant to capture the reactions of others directly, whether verbally or nonverbally. Interpersonal communication is communication that only two people, such as husband and wife, two colleagues, two close friends, teacher-students and so on. ${ }^{20}$

Whereas interpersonal communication (interpersonal communication) is communication between people face to face, which allows verbal and nonverbal responses to take place directly. ${ }^{21}$

\section{Conclusion}

In carrying out the mission of amar ma'ruf nahi mungkar in the city of Lhokseumawe, Wilayatul Hisbah has implemented two communication patterns, first; namely: supervise the implementation of legislation in the field of Islamic Shari'a. In this case Wilayatul Hisbah socializes to the community to change behavior, strengthen and maintain the attitudes, beliefs, decisions and behavior of others who in communication terminology are referred to as communicants with the approach of the potential side or weakness of the communicant so that changes made on the basis of their own desires, not coercion done by communicators. The persuasive approach puts forward human aspects.

Communicants are given the freedom to consider the advantages and disadvantages of the suggested aspects or those conveyed by communicators. The human aspect or social communication carried out by the Wilayatul Hisbah City of Lhokseumawe is to install billboards in the middle of Lhokseumawe City in anticipation of Islamic Sharia offenders and enforcement of amar ma'ruf nahi mungkar. In this case, it cannot be separated from persuasive communication in the form of non-verbal media in the Islamic communication approach. That is preventative communication. This communication is also a form of communication used by the Wilayatul Hisbah City of Lhokseumawe in socializing its activities to the public directly or verbal communication. Like in Friday sermons or preaching, recitation and appeals for the implementation of Islamic Law in the city of Lhokseumawe. The things as mentioned above are interpersonal communication generally applied in activities to supervise the implementation and prevention of Islamic Sharia. This means that Wlayatul Hisbah in terms of efforts to provide insights about the Islamic Sharia law, is more dominant between two people; communicator and communicant only.

This activity aims to be carried out by the Wilayatul Hisbah City of Lhokseumawe in overcoming sharia violations committed by the community in four sub-districts, namely Banda Sakti District, Muara Dua, Blang Mangat and Muara Satu Districts. In addition, the oversight carried out by the Wilayatul Hisbah through mass media, namely the process of organizing media organizations to create and disseminate messages to the public (public). In mass communication it is the sole authority that selects, produces messages and delivers them to the public. For example: news on socialization and raids, both on internet media, newspapers, magazines, leaflets and others. Second: conduct spiritual guidance and advocacy, which is to carry out a religious approach for those who violate Islamic Shari'a by

\footnotetext{
${ }^{20}$ Dedy Mulyana, Ilmu Komunikasi, Pengantar,(Bandung:Remaja Rosdakarya, 2000), p. 73.

${ }^{21}$ Ibid, p.51.
} 
reprimanding, advising and reminding every member of the community that has deviated from the Islamic Shari'a regulations.

\section{References}

A. Hasjmy, Dustur Dakwah Menurut Al-Quran, Jakarta: Bulan Bintang, 1994.

A. Rahmat Rosyadi, dan M. Rais Ahmad, Formalisasi Syariat Islam DalamPerspektif Tata Hukum Indonesia, Bogor: Ghalia Indonesia, 2006.

Abu Ya'la Muhammad Ibn al-Husaini al-Farra', al-Alkām al-Sulthāniyyāh, Mesir: Matba'ah Mustāfa al- Bābī al- Halabī, 1973.

Elbi Hasan Basri, Metode Dakwah Islam, Kontribusi Terhadap PelaksanaanSyari 'at Islam di Provinsi NAD, Banda Aceh: Ar-Raniry Press, 2006.

Furqoni dalam Rena Kinnara Arlotas: Gambaran Coping Stres pada Wilayatul Hisbah yang di Tempatkan di Desa.USU Repository,Medan, 2010 .

Hafied Cangara, Pengantar Ilmu Komunikasi. Jakarta: Raja Grafindo

Husnul Arifin Melayu, "Eksistensi Wilayat al-Hisbah dalam Islam” dalam Soraya Devy, dkk,Politik dan Pencerahan Peradaban, Banda Aceh: Ar-Raniry Press, 2004.

Juhari, "Peran Wilayatul Hisbah Dalam Menegakkan Dakwah Struktural di Kota Banda Aceh" dalam Muslim Zainuddin, dkk, Agama dan Perubahan Sosial Dalam Era Reformasi di Aceh, Banda Aceh: Ar-Raniry Press, 2004.

Kertas Kebijakan Materi Dialog, kebijakan Komnas Perempuan Tentang Pelaksanaan Syariat Islam di Aceh,Banda Aceh,10 Oktober 2005.

Lexy J. Moleong, Metodologi Penelitian Kualitatif,Bandung:Remaja Rosdakarya, 2005.

Louis Ma'luf, al-Munjid fi al-Lughah wa al-'A 'lam, Beirut: Dār al-Masyriqi, 1997.

M. Burhan Bungin, Sosiologi Komunikasi; Teori, Paradigma, dan Diskursus Teknologi Komunikasi di Masyarakat, (Jakarta: Kencana), 2008.

M. Hasbi Amiruddin, Republik 'Umar bin Khatab, Yogyakarta: Total Media, 2010.

M. Tata Taufik, Etika Komunikasi Islam; Komparasi komunikasi Islam dan Barat, Bandung: Pustaka Setia, 2012.

Moleong, Metodelogi Penelitian Kualitatif, Remaja Rosda Karya, Bandung, 1989.

Morissan, Teori Komunikasi Individu Hingga Massa. KDT. Jakarta2013.

Muh. Zuhri, Potret Keteladanan Kiprah Politik Muhammad Rasulullah, Yogyakarta: LESFI, 2004.

Muhammad Abdul Qadir Abu Fariz, Sistem Politik Islam, Jakrta: Rabbani Press, 2000.

Muhammad Ahmad al-Rasyid, al-Muntalaq, terj Abu Sa'id al- Falahi, Titik Tolak: Landasan Gerak Para Aktivis Dakwah, Jakarta: Robbani Press,

Richard L. Johannesen, Ethics in Human Comunication dalam Dedy Jamaluddin Malik, Etika Komunikasi, (Bandung: Remaja Rosdakarya), 1996.

Ridwan Hasan, hukum adat Vs Teologi dan Syariat Islam dalam Wilayatul Hisbah Di Nanggroe Aceh Darussalam (NAD), The $9^{\text {th }}$ Annual Conference On Islamic Studies (ACIS), Surakarta 2009,hlm 1.

Rosadakarya, 2005.

Ruben, Brend D dan Lea P. Stewart. 2013. Komunikasi dan Prilaku Manusia.

Rusjdi Ali Muhammad, Revitalisasi Syari'at Islam di Aceh, Problem, Solusi, dan Implementasi, Jakarta: Logos Wacana Ilmu, 2003.

Santosa, Slamet. Dinamika Kelompok. Jakarta: Bumi Aksara, 2006. 
Sayyid Muhammad, Al-Wahdāt al-Islamiyyāh, terj Ali Yahya, Persatuan Islam, Jakarta: Lentera Baristama, 1997.

Sehat Ihsan Shadiqin, Islam Dalam Masyarakatkosmopolit: Relevankan Syariat Islam Aceh Untuk Masyarakat Modern, Annual Conference on Islamic Studies Banjarmasin, 1-4, November 2010.

Topo Santoso, Membumikan Hukum Pidana Islam, Penegakan Syari'at DalamWacana danAgenda, Jakarta: Gema Insani Press, 2003.

Tresna," Bertamasya Ketaman Ketatanegaraan," Dibya,Bandung, 1998.

Wahbah al-Zuhailȳ, al- Fiqh al- Islamiyyi wa Adillatuh, Dimasq: Dār al- Fikri, 1997.

Wahyu Ilaihi, Komuniaksi Dakwah, (Bandung: Rosdakarya), 210.

Yusuf al-Qaradhawy, al-Siyāsat al-Syar'iyyāh terj Kathur Suhardi, Pedoman Bernegara Menurut Perspektif Islam, (Jakarta: Pustaka al-Kautsar, 1999.

Zubir Rahman, Eksitensi Jaksa ditengah-tengah Masyarakat, Ghalia Indonesia, Jakarta, 1985. 